\title{
Women Empowerment through SHGs with Reference to District Ganderbal
}

\author{
Zahoor Bhat", Rizwana Malik, S. H. Baba, Bilal Ahmad Bhat and T. H. Shah \\ Faculty of Fisheries SKUAST-K Rangil Ganderbal, JK, India \\ *Corresponding author
}

Keywords

Poverty, Inefficient trainings,

Ganderbal, Positive,

Social benefits,

Skill improved

Article Info

Accepted:

12 December 2020

Available Online:

10 January 2021

\section{A B S T R A C T}

\section{Introduction}

The idea of microfinance was created from the disappointments of the formal banking frameworks. Destitute people have regularly been deprived of financial services, and the possible solution to tackle with this problem was emergence of microfinance or village financing system (Brau \& Woller, 2004). The arena of microfinance that we see of today stem from the economic try-out showed by Muhammad Yunus in 1970's in Bangladesh. Yunus, an Economics Professor at the Chittagong University, conjectured that lending small amounts of money to poor people, despite their dearth of collateral mortgage, would empower them to run smallscale income engendering activities, repay loans, and pull themselves out of poverty (Armendáriz \& Morduch, 2010). The development sectors in India has achieved moderate expansion even after more than seventy years of colonial regime ended.

The major hinges that still hamper the growth of this diverse and beautiful country are unemployment in large masses and poverty in rural areas as they rely on unorganized sector Monetary resources play a prevalent role in different economic activities carried by the rural people, as of the fact that the significant number of rural people are very poor. In a country where vicious circle of poverty 
operates, the downtrodden people of villages are not able to go for capital formation as the income from their activities is unable to meet their basic requirements of life like food, clothes and shelter. Then the question of income generating activities still hangs in limbo.

The significance of finance is realized in the development of rural population especially women. Various financial institutions such as Government, Co-operatives, commercial banks, regional rural banks entered into the scenario for the provision of institutional credit.

The scenario of rural credit has rapidly changing overtime. The different exercises like provincial microcredit decreased the monetary reliance of women upon different individuals from the family and the trainings and information empowered the women to start financial activities. Consequently, women could utilize the combination of credit and trainings to improve their livings by enhancing their pay sources and decreasing reliance.

The gathering and mindfulness programs expanded the information and experience which prompted an expansion in the capacity of settling on quality choices and guarantee interest. Taking an interest in the social control exercises, women had the option to steadily bring down the customary and social boundaries for partaking in the advancement cycle.(Dahal 2017).

Self-Help Groups (SHGs) are micro credit institutions, which have emerged at the village level based on self-help, collective perception, decision making and implementation of common programs.

SHGs are now occupying a predominant position in the rural credit delivery system. Self-help groups (SHG), also known as joint help, common aid, or backing groups, are assemblies of people who deliver mutual support for each other. Their common goal is to aid each other to deal with, if probable to heal or to recuperate from, this delinquent.

A number of studies have been conducted so far in the world especially in the developing countries to study the impact of SHGs on women empowerment and its effect on poverty alleviation. In our country, a lot of research has been done by the scholars to study performance of SHGs but in Jammu and Kashmir a little work has been done on the same topic.

Puhazhendi and Satyasai (2000) conducted a study in Rajasthan, Odisha, West Bengal, Madhya Pradesh, Gujarat, Maharashtra, Andhra Pradesh, Karnataka and Tamil Nadu and concluded that impact of Micro Finance (SHGs) is more pronounced on social aspects than economic aspects. Rao (2000) in his study found that SHGs showed a positive impact in respect of building of selfconfidence, social development, skill formation and social empowerment among the members of SHGs in Andhra Pradesh.

Mosley (2001) cited in his study how in Bolivia the assets and income were increased commensurate with the micro-finance activities. Manimekalai and Rajeswari (2001) in their study in Tamil Nadu has concluded that SHGs has helped the groups to achieve economic and social empowerment.

It has built up a feeling of authority, authoritative expertise, the executives of different exercises of a business, directly from securing funds, distinguishing crude material, market and appropriate expansion and modernization. Mallick (2002) explained in his study in Bangladesh the social impact of micro-credit that already started to surface there. 
Satyasai (2003) stated that Micro finance had positive impact in respect of self-confidence, economic and social development and skill formation in Andhra Pradesh and social empowerment in Tamil Nadu.

Silivia (2004) reported in his study conducted in Karnataka that SHGs has brought Positive changes in income and women actively participated in community activities. Usha et al., (2004) reported that Micro credit amplified the access to financial resources and it made poor women financially selfreliant in Andhra Pradesh.

\section{Materials and Methods}

The current study practices diverse technique approach. Diverse approach study permits for inclusion of both qualitative and quantitative methods of data collection and/or analysis to achieve a range of outcomes as discussed by Creswell (Creswell, 2005); and Greene et al., (Greene, Caracelli, \& Graham, 1989). Jammu and Kashmir is located in northern part of India with hilly terrain unique geographical and climatic features.
The erstwhile state was divided into three divisions (Jammu, Kashmir and Ladakh). Keeping in view the objectives of our study Ganderbal district were selected for our study. District Ganderbal was selected purposively as it contains good number of SHGs and has the distinction of being $1^{\text {st }}$ district with SHGs.

A good number of women were found to be registered as SHG members, but all of them were not active. For our study only active members were taken into account. The selection of SHGs was done in consultation with National Rural Livelihood Mission Ganderbal. The list produced by NRLM revealed 1239 SHG were formed. But for the study purposes successful SHGs that were functional from past 5 years were taken into consideration.

The performance of these SHGs was analysed and audited by banks and other financial organizations Out of which 83 SHG members were selected through purposive sampling. The numbers of SHGs from each block are as under:

\begin{tabular}{|c|c|c|c|}
\hline S.No & Block & Number of SHGs & Women enrolled in SHGs \\
\hline 1. & Lar & 385 & 3716 \\
\hline 2. & Ganderbal & 409 & 3230 \\
\hline 3. & Kangan & 445 & 3810 \\
\hline
\end{tabular}

\section{Selection of respondents}

Out of the total SHG members, 83 members constituted the sample of this study. The selection of respondents was done on the basis of

1. Performance of SHGs.

2. Performance of individual members.

3. Savings of members.

4. Frequency of meetings attended.
5. Income generating activities undertaken by members and

6. Individual assets edifice of members.

From VO (village organization) the list of registered as well as active members were procured. Meanwhile from the VO the closed SHGs and unsuccessful ones were also acquired and they were bought into the fold of FGD (focused group discussion). 


\begin{tabular}{|c|c|c|}
\hline \multicolumn{3}{|c|}{ A. Independent variables } \\
\hline 1. & Age & Chronological age index developed \\
\hline 2. & Education & $\begin{array}{c}\text { SES (rural) } 1964 \text { developed by Trivedi and Pareek with } \\
\text { some modifications }\end{array}$ \\
\hline 3. & Family & $\begin{array}{c}\text { SES (rural) } 1964 \text { developed by Trivedi and Pareek with } \\
\text { some modifications }\end{array}$ \\
\hline 4. & Family size & -do- \\
\hline 5. & Land holding & As per GOI norms \\
\hline $\begin{array}{l}6 . \\
\mathbf{O}\end{array}$ & Housing pattern & $\begin{array}{c}\text { SES (rural) } 1964 \text { developed by Trivedi and Pareek with } \\
\text { some modifications }\end{array}$ \\
\hline 7. & Occupation & -do- \\
\hline 8. & Participation in extension activities & -do- \\
\hline 9. & Annual income & Income class index developed and used. \\
\hline
\end{tabular}

\section{Dependent variables}

\begin{tabular}{|c|c|}
\hline $\begin{array}{c}\text { Skill Improved } \\
\text { Benefits derived as member } \\
\text { of SHGs }\end{array}$ & $\begin{array}{c}\text { Index was developed and used } \\
\text { Index was developed and used }\end{array}$ \\
\hline Loan Utilization & Index was developed and used \\
\hline
\end{tabular}

\section{Results and Discussion}

It is obvious from the Table. 1 that maximum number of members $(34.93 \%)$ were found to be in the age category of 27-39 followed by the age group of 18-26 (33.7 \%) and then 4055 (25. \%). The result indicates that respondents within the age group of 27-39 are young, sagacious and energetic. They have high aspirations and therefore more interested to find opportunities to enhance their livelihood. They could be easily motivated to participate in programs designed for their growth and development.

\section{Education}

The table. 2 reveals that majority $(72.2 \%)$ of the members were educated upto $10^{\text {th }}$ class or below. Followed by 18.07 having education upto higher secondary. A meagre percentage of $3.6 \%$ and $6.2 \%$ were graduates and post graduates respectively. Education plays an important role in the socio-economic development of an individual.

However, the illiteracy and low educational status was found among the majority of SHG member that could be attributed to no. of reasons. Poor school infrastructure, inadequate sanitation facilities in schools, less awareness among the parents about the importance of girl child education were few reasons cited by the members.

\section{Socio-Economic Profile of SHG members}

\begin{tabular}{|l|l|l|l|}
\hline S.No & Age categories( in years) & Members & \\
\hline & & Number & Percentage \\
\hline 1. & $18-26$ & 28 & 33.70 \\
\hline 2. & $27-39$ & 29 & 34.93 \\
\hline 3. & $40-55$ & 25 & 30.12 \\
\hline 4. & $>55$ & 1 & 0.012 \\
\hline
\end{tabular}


It is evident from the Table. 3 that 64 per cent members of SHGs had small families having upto 5 members in their family. $36 \%$ of respondents had larger families having more than 5 family members. The reasons behind prevalence of nuclear families may be the inflation that takes toll on income and due to increased cost of living people find it difficult to maintain large families and prefer nuclear families.

\section{Land holding}

Table 4 reveals that $76 \%$ of members were marginal farmers. Marginal farmers having land upto 1 kanal and 24 per cent possessed more than one kanal of land. The main reason behind possession of small land holdings could be the prevalence of nuclear families. Division of properties could be seen leading to fragmentation of land holdings. Conversion of agricultural land into residential areas, also leads to the decreasing share of land holdings as well as attracts people towards selling their land because of higher returns fetched by selling land.

\section{Housing pattern}

It is apparent from the data given in Table 5 pertaining to the type of house possession that 80 per cent member had pucca house while as 20 per cent were residing in kuchha houses. The people tend to have better and sophisticated amenities with the growing times and housing is one of them. The other factors include availability of construction material that include sand, boulders, stones. The construction material used is mined/excavated locally from streams and mountains.

Table 6 reveals the occupation of the members of SHGs. The highest number of members $(71 \%)$ reported housewives as their domain followed by students (16.8\%), government employees (3.6\%), tailoring (6\%) and needle work $(2.4 \%)$. The findings of the study indicated that housewives have highest participation (71 percent) in SHGs, followed by $16.6 \%$ students. The main factors for their higher share are availability of time, desire to earn more income from different sources, passion to excel in social participation and to walk shoulder to shoulder with working women.

\section{Annual income of family}

Members of SHGs were categorized into three categories based on their income level as per NITI Aayog. Majority (61.8\%) belong to middle class with an annual income of 1-5 lac followed by lower class (37\%) with annual income of less than 1 lac and high class $(1.2 \%)$ with annual income of greater than 5 lac.

The major findings of the study concluded that 62 percent of participation in SHG were from middle class. Since India is an agrarian country and more people belong to middle class and their high participation can be attributed to few factors like better awareness, knowledge about various social programs, information flow from officials and accessibility to various information sources like radio, T.V and newspapers

A glance over the data in the Table.7 depicted that $52 \%$ of the members don't have any participation while as $48 \%$ of the members have attended one or more extension activities gatherings (in the form of Panchayat meetings, tours and training programs). The findings of the study revealed negligible participation of women SHG members in extension activities. Though training programs and tours were organized by state agricultural universities through KVKs and line departments also but those programs are not based on needs and interest of women. 
Mostly they are male oriented and are formulated keeping in view the interests of men. One of the reason is absence of female extension worker. As women feel hesitant to participate in programs organized by male extension functionaries.

Table.1 Distribution of members of SHGs according to Education N=83

\begin{tabular}{|l|l|l|l|}
\hline S .No & Category & Members & \\
\hline & & Number & Percentage \\
\hline 1. & $10^{\text {th }}$ and below & 60 & 72.2 \\
\hline 2. & Higher secondary & 15 & 18.07 \\
\hline 3. & Graduate & 3 & 3.6 \\
\hline 4. & Post graduate & 5 & 6.2 \\
\hline
\end{tabular}

Table.2 Distribution of members of SHGs according to size of family N=83

\begin{tabular}{|l|l|l|l|}
\hline S. No & Category & Members & \\
\hline & & Number & Percentage \\
\hline 1. & Upto 5members & 53 & 64 \\
\hline 2. & $>5$ members & 30 & 36 \\
\hline
\end{tabular}

Table.3 Distribution of members of SHGs according to size of land holding N=83

\begin{tabular}{|l|l|l|l|}
\hline S .no & Category & Members \\
\hline & & Number & Percentage \\
\hline 1. & Marginal Farmers (upto 1 kanal) & 63 & 76 \\
\hline 2. & Small farmer (> 1 kanal) & 20 & 24 \\
\hline
\end{tabular}

Table.4 Distribution of members of SHGs according to housing pattern

\begin{tabular}{|l|l|l|l|}
\hline S.no & Categories & Members & \\
\hline & & Number & Percentage \\
\hline 1. & Kuchha house & 17 & 20 \\
\hline 2. & Pucca house & 66 & 80 \\
\hline 3. & Total & $\mathbf{8 3}$ & $\mathbf{1 0 0}$ \\
\hline
\end{tabular}


Table.5 Distribution of members of SHGs according to occupation

\begin{tabular}{|l|l|l|l|}
\hline S.no & Categories & Members & \\
\hline & & Number & Percentage \\
\hline 1. & Student & 14 & 16.8 \\
\hline 2. & Housewife & 59 & 71 \\
\hline 3. & Government employee & 3 & 3.6 \\
\hline 4. & Needle work & 2 & 2.4 \\
\hline 5. & Tailoring & 5 & 6 \\
\hline
\end{tabular}

Table.6 Distribution of members of SHGs according to income class (Rs.)

\begin{tabular}{|l|l|l|l|}
\hline S.no & Category & Members & \\
\hline & & Number & Percentage \\
\hline 1. & Lower class( upto 1 lac) & 31 & 37.0 \\
\hline 2. & Middle class (1-5 lac) & 51 & 61.8 \\
\hline 3. & Higher class (> 5 Lac) & 1 & 1.20 \\
\hline
\end{tabular}

Table.7 Distribution of SHG members according to Extension activities

\begin{tabular}{|l|l|l|l|}
\hline S. No & Category & Member & \\
\hline 1. & Attend & 40 & 48.00 \\
\hline 2. & Don't attend & 43 & 52.00 \\
\hline
\end{tabular}

Table.8 Distribution of SHG members according to the economic activities established

\begin{tabular}{|l|l|l|l|}
\hline S.No & Category & \multicolumn{2}{|c|}{ Member } \\
\cline { 3 - 4 } & & Number & Percentage \\
\hline 1. & Animal husbandry & 48 & 58.00 \\
\hline 2. & Agricultural activities & 28 & 33.00 \\
\hline 3. & Shops & 7 & 9.00 \\
\hline
\end{tabular}

Table.9 Distribution of SHG members according to Skill improved by SHGs

\begin{tabular}{|l|l|l|l|}
\hline S.no & Category & Member \\
\cline { 3 - 4 } & & Percentage & Number \\
\hline 1. & Communication skill & 32 & 41 \\
\hline $\mathbf{2 .}$ & Management skill & 28. & 36 \\
\hline $\mathbf{3 .}$ & Confidence & 40 & 52 \\
\hline $\mathbf{4 .}$ & Total & $\mathbf{1 0 0}$ & $\mathbf{1 2 9}$ \\
\hline
\end{tabular}


Table.10 Distribution of SHG members according to the benefits of being SHG members

\begin{tabular}{|l|l|l|l|}
\hline S.no & \multirow{2}{*}{ Category } & \multicolumn{2}{|c|}{} \\
\cline { 3 - 4 } & & Percentage & Number \\
\hline 1. & Social & 33 & 38 \\
\hline 2. & Domestic & 32 & 36 \\
\hline 3. & Financial & 35 & 40 \\
\hline 4. & Total & $\mathbf{1 0 0}$ & $\mathbf{1 1 4}$ \\
\hline
\end{tabular}

Table.11 Distribution of SHG members according to loan utilization

\begin{tabular}{|r|l|l|l|}
\hline S.no & Category & \multicolumn{2}{|c|}{} \\
\cline { 3 - 4 } & & Percentage & Number \\
\hline $\mathbf{1 .}$ & Domestic & 50 & 77 \\
\hline 2. & Income & 25 & 39 \\
\hline $\mathbf{3 .}$ & Health & 4 & 6 \\
\hline $\mathbf{4 .}$ & Education & 21 & 33 \\
\hline $\mathbf{5 .}$ & Total & $\mathbf{1 0 0}$ & $\mathbf{1 5 5}$ \\
\hline
\end{tabular}

Table.12 Distribution of SHG members according to the trainings imparted

\begin{tabular}{|r|l|l|l|}
\hline S.no & Trainers & \multicolumn{2}{|l|}{} \\
\cline { 3 - 4 } & & Percentage & Number \\
\hline 1. & SHGs & 17 & 16 \\
\hline 2. & Village Organisation & 23 & 21 \\
\hline 3. & Cluster level Federation & 19 & 18 \\
\hline 4. & Block Project manager & 5 & 5 \\
\hline 5. & NRLM & 9 & 8 \\
\hline 6. & Nill & 27 & 25 \\
\hline 7. & Total & $\mathbf{1 0 0}$ & $\mathbf{9 3}$ \\
\hline & & & \\
\hline
\end{tabular}

Table.13 Correlation table of skill improved with Age, Education, Occupation, trainings

\begin{tabular}{|l|l|l|l|}
\hline $\begin{array}{l}\text { Independent } \\
\text { Variable }\end{array}$ & $\begin{array}{l}\text { Dependent } \\
\text { variable }\end{array}$ & $\begin{array}{l}\text { r(Coefficient of } \\
\text { Co-relation) value }\end{array}$ & p value \\
\hline Skill improved & & -0.09 & $0.042 * *$ \\
\hline Age & & 0.155 & $0.016 * *$ \\
\hline Education & & $-\mathbf{0 . 1 4 2}$ & $\mathbf{0 . 1 9 7}$ \\
\hline Occupation & & $\mathbf{- 0 . 2 1 2}$ & $\mathbf{0 . 0 4 5} * *$ \\
\hline Trainings & & & \\
\hline
\end{tabular}


Table.14 Correlation table of Benefits derived as member of SHG with Age, Education, Occupation, trainings

\begin{tabular}{|l|l|l|l|}
\hline $\begin{array}{l}\text { Independent } \\
\text { Variable }\end{array}$ & Dependent variable & $\begin{array}{l}\text { r(Coefficient of } \\
\text { Co-relation) value }\end{array}$ & p value \\
\hline & $\begin{array}{l}\text { Benefits derived as } \\
\text { member of SHG }\end{array}$ & & \\
\hline Age & & -0.290 & $0.007 * *$ \\
\hline Education & & 0.139 & $0.029 * *$ \\
\hline Occupation & & -0.1403 & 0.205 \\
\hline Trainings & & 0.013 & $0.029 * *$ \\
\hline
\end{tabular}

**Correlation is significant at the 0.05 level (2-tailed)

Table.15 Correlation table of loan utilization by SHG members with Age, Education, Occupation, trainings

\begin{tabular}{|l|l|l|l|}
\hline $\begin{array}{l}\text { Independent } \\
\text { Variable }\end{array}$ & Dependent variable & $\begin{array}{l}\text { r(Coefficient of Co- } \\
\text { relation) value }\end{array}$ & p value \\
\hline & Loan utilization & & \\
\hline Age & & $\mathbf{- 0 . 1 9}$ & $\mathbf{0 . 0 7 7}$ \\
\hline Education & & $\mathbf{0 . 0 0 8}$ & $\mathbf{0 . 0 3 9} * *$ \\
\hline Occupation & & $\mathbf{- 0 . 1 5 5}$ & $\mathbf{0 . 1 5 9}$ \\
\hline Trainings & & $\mathbf{- 0 . 0 2 1}$ & $\mathbf{0 . 0 8 4}$ \\
\hline$* *$ Correlation is significant at the 0.05 level (2-tailed) & & \\
\hline
\end{tabular}

It is evident from the table. 8 that the animal husbandry was the foremost preference $(58 \%)$ or most favoured option for livelihood enhancement among the SHG members followed by other agricultural activities (33\%) like developing kitchen garden etc. Business initiatives like establishing shops was the least preferred among the SHG members. Animal husbandry in rural area is one of the major avenue for rural women to earn good amount of money. Animal husbandry is preferred in the study area due to availability of good breeds (Introduced by State Agricultural Universities through Krishi Vigyan Kendras and Animal husbandry department initiatives). Availability of fodder in vast amount in rural areas, use of animals in farming and use of cattle dung as manure, high demand of milk and milk are cash asset.

The Table. 9 depicts that $40 \%$ of the members felt that SHG inculcated confidence in them while as $28.4 \%$ and $31.6 \%$ felt being the member of SHG instilled management and communication skills respectively.. The respondents revealed that their ability to talk at social gatherings, ability to talk with officials and any other authority with whom they were hesitant to talk before joining the developmental program had enhanced. The respondents cited that their management skill got improved after joining the SHG as they got opportunity to liaise with different people within and outside their group.

From the table.10 it is clear that there was almost similarity in perception of SHG members toward benefits of being SHG members $35 \%$ members stated that it empowered them financially while as $33 \%$ and $32 \%$ stated that it empowered them socially and domestically respectively.. Since 
SHGs are providing soft loans and loans without any collateral mortgage, members find it easy to lend money to other family members and that helps indirectly in women empowerment by increasing their say in decision making processes $33 \%$ stated that being the member of SHG, it empowered/benefitted them socially and enabled them to husband their financial resources. Socially empowerment stated by respondents included that when they lend monetary assistance to the family members, it enhances a status quo among society which helped them to feel empowered.

From the table. 11 it is clear that the majority of the loan utilization goes in domestic consumption $(50 \%)$ followed by income generation activities (25\%), Education (21\%), and Health (4\%). When the members were asked for what purpose the loans was used. The members stated that they bought house amenities like refrigerators, crockery items, renovation of houses, and the loans were also utilized for social functions like marriages etc. Thus the loans secured by the SHG members enabled them to enhance their say in various decision making processes.

From the table. 12 it is clear that majority $(25 \%)$ of the SHG members have not undergone any trainings programs. While as $21 \%$ have undergone trainings at village level conducted by village organization. $18 \%$ members were trained by CLFs (cluster level federations). $16 \%$ members were trained by SHGs themselves. $8 \%$ and $5 \%$ were trained by NRLM (National Rural Livelihood Mission) and BPM (Block Project Manager) respectively.

The study was aimed to comprehend the functioning of SHGs, identify their constraints and also the factors contributing towards their smooth functioning and success so that the study could act as a guide for formulation of successful SHGs in fishing community. From the research conducted the following conclusion could be drawn: A negative and significant co-relation was found between age and skill. This implies that with age, people tend to become less interested and less enthusiastic in learning new skills and improvising or enhancing their potential. This statement is supported by the fact that majority of members of SHGs in the study area were young and middle aged and therefore opted to be the SHG members to learn new things and to acquire new skills through these SHGs. Therefore, whenever formation of SHGs is planned in fishing community young and middle-aged people must be given preference as the they are expected to be more eager to participate and learn through SHGs.

Education was found to be positively and significantly correlated with skill. This shows educated people learn skills easily. Though studies have shown that literacy level among fishers is low however, during formation of Fisher SHGs it must be ensured that at least one member must be literate who will facilitate the accounting, bookkeeping and other such activities.

Trainings were negatively and significantly correlated with skill improved. It was found that very few trainings were conducted for SHG members and the ones conducted were not result oriented and the motive of trainings was not achieved. This indicates that SMART (specific, measurable, attainable, realistic and time bound) trainings must be one of the goals while fisher SHGs are formed. SMART trainings can help them gain expertise, enhance skill, and improve their socioeconomic status. The study also revealed that the low participation of respondent SHG members in trainings was due to their busy schedule. Hence timing of the trainings was also one of the important things to be taken 
care of in Fisher SHGs. Trainings must be imparted during the lean season as during this period fishers have leisure time to attend training programs and unlike SHGs in the study area fisher SHGs shall avail the benefits from trainings.

SHGs that were studied were found to be provided with irregular and insufficient supply of funds that hindered the smooth functioning of groups. Therefore, fisher SHGs when formed must be provided with regular funds. There should be transparency in allocation of funds and allotted on the basis of performance of SHGs.

Workshops must be organised for members to inculcate entrepreneurial behaviour in them so that SHGs don't remain as mere saving groups but develop as successful start-ups leading to their over-all growth and development and ultimately to raised Human development index.

\section{References}

Brau, J., and Woller, G., 2004. Microfinance: A comprehensive review of the existing literature. Journal of Entrepreneurial Finance, 9(1): 1-27.

Armendáriz, B., and Morduch, J., 2010. The Economics of Microfinance. Cambridge, Mass: MIT Press.

Dahal, S., 2017. A study of Women's self help groups and the impact of SHG participation on women empowerment and livelihood in Lamachaur village of Nepal. Master Thesis in International Development Studies. Norwegian University of Life Sciences. Norway.

Puhazhendi, V., and Satyasai, K.J.S., 2000.Microfinance for Rural People: $A n$ Impact Evaluation. NABARD. Mumbai.

Rao,V.M., 2004.Empowering Rural Women. New Delhi: Anmol Publications pp 150-
210.

Mosley, P., 2001. Microfinance and Poverty in Bolivia. Journal of Developmental Studies. 37(4):101-132.

Manimekalai, M., and Rajeswari, G., 2001. Nature and Performance of Informal Self Help Groups: A case from Tamil Nadu, Indian Journal of Agricultural Economics, 56(3), 453-54.

Mallick, R., 2002.Implementing and evaluating microcredit in Bangladesh. Development in Practice. 12(2):153163.

Satyasai, K.J.S. 2003. Micro finance in India: Progress and Perspective. Institutional change in Indian Agriculture. New Delhi: National Centre for Agricultural Economics and Policy Research. pp 305- 320.

Silvia, S., 2004.Microfinance through Self Help Groups. International Journal of Marketing, Financial services and Management Research.12(1):110-125.

Usha, R, Reddy., D.P.J., and Reddy, M.V.S.,2004. Women Development: Empowerment through Self Help Groups in Andhra Pradesh. Communication and Empowerment of Women. The Women Press. New Delhi. Pp 616-624.

Creswell, J.W., 2005. Educational Research: Planning, Conducting, and Evaluating Quantitative and Qualitative Research. Pearson Education. New Jersey. pp 694709.

Greene, J.C., Caracelli,V.J., and Graham, W.F., 1989. Towards a conceptual Framework for Mixed-Method Evaluation Designs. Educational Evaluation and Policy Analysis. 11(3):255-274.

Pareek, U., and Trivedi, G., 1964. Manual of Socio- Economic Status (Rural). Manasayan Publishers. New Delhi. 


\section{How to cite this article:}

Zahoor Bhat, Rizwana Malik, S. H. Baba, Bilal Ahmad Bhat and Shah, T. H. 2021. Women Empowerment through SHGs with Reference to District Ganderbal. Int.J.Curr.Microbiol.App.Sci. 10(01): 1636-1647. doi: https://doi.org/10.20546/ijcmas.2021.1001.191 